\title{
Sexual self-esteem and sexual needs of young adults with cerebral palsy
}

\begin{abstract}
BACKGROUND
Sexuality is an important part of human existence, irrespective of race, religion or level of physical fitness. It can, however, be treated and exhibited by individuals in very different ways. The place of sexuality in a person's life, and in the way it is materialised, is determined by a number of biopsychosocial factors. For some, the presence of these factors and their influence is not a matter of choice. They may arise as a consequence of the psychophysical condition of their organism. People with motor disabilities undoubtedly belong to this group.
\end{abstract}

\section{PARTICIPANTS AND PROCEDURE}

The study was carried out in Poland on a group of 61 people with roughly equal proportions of men and women. Subject selection was non-random; every subject was diagnosed with cerebral palsy (CP) and was aged between 15 and 25. All of the subjects had normal levels of intelligence. Two methods were used in the study: Sexual Self-esteem Scale and Sexual Needs Scale.

\section{RESULTS}

The results in terms of sexual self-esteem and sexual needs allowed two different subgroups of subjects to be distin- guished ( $\mathrm{H}$ - with high scores; $\mathrm{L}$ - with low scores). The analysis of significance levels of the differences in terms of sexual self-esteem and sexual needs between subgroups $\mathrm{H}$ and $\mathrm{L}$ confirmed the clear distinction between each of the subgroups' clinical pictures $(p<.001)$ in 20 out of 21 of the analysed aspects. Falling in love was the only matter that did not differentiate the subgroups.

\section{CONCLUSIONS}

There is a clear polarization of the results. Only $1 / 3$ of the respondents had high sexual self-esteem and sexual needs. The remaining $2 / 3$ reported having a rather low sexual self-esteem and low levels of needs with regards to their own sexuality. It needs to be stressed that CP-affected youth, similarly to their peers, may need support in discovering their sexuality and satisfying their sexual needs $(2 / 3$ of the respondents). The specifics of the range of support should take into account the aspects highlighted by the literature as associated with the causes of disability and contexts of psychosocial functioning of individuals with CP.

KEY WORDS

cerebral palsy; disability; sexual behavior 


\section{BACKGROUND}

Sexuality is an important part of human existence, irrespective of race, religion or level of physical fitness (Szczerba, 2004). It can, however, be treated and exhibited by individuals in very different ways. The place of sexuality in a person's life, and in the way it is materialised, is determined by a number of biopsychosocial factors. For some, the presence of these factors and their influence are not a matter of choice.

Klaudia Czapla, Wojciech Otrębski
They may arise as a consequence of the psychophysical condition of their organism. People with motor disabilities undoubtedly belong to this group.

When considering the topic of sexuality in scientific research or rehabilitation practice, one should remember that human sexuality is a very complex phenomenon that is not limited to mere sexual activity. Among many of its characteristics, sexual esteem and sexual needs are important and vital to the proper development of an individual. They are specific cases of what we define as global self-esteem and psychological needs.

A number of definitions of self-esteem can be found in the literature. It can be seen as: "a way to think about oneself, which simulates positive (in the case of high self-esteem) or negative (in the case of low self-esteem) emotions" (Porębiak, 2005, p. 93), or as Markus describes it (1977, p. 75) "self-schemata are cognitive generalizations about the self, derived from past experience, that organize and guide the processing of the self-related information contained in an individual's social experience". Campbell proposed an interesting and theoretically useful distinction between self-knowledge (Who am I?) and self-evaluation (How do I feel about who I am?) (Campbell \& Lavaalle, 1993).

Similarly, the notion of sexual self-esteem is defined in multiple ways. Snell and Papini (1989, p. 256) defined sexual self-esteem "as a generalized tendency to positively evaluate one's own capacity to engage in healthy sexual behaviours and to experience one's sexuality in a satisfying and enjoyable way". Taleporos and his co-workers (Taleporis, Hons, Dip, \& McCabe, 2002, p. 177) understood it as a "positive regard for and confidence in an individual's capacity to experience his or her sexuality in a satisfying and enjoyable way". Moin, Duvdevany and Mazor (2009, p. 84) defined sexual self-esteem "as one's self-perception of being a good or bad sexual partner". Kirenko and Lew-Starowicz (2001) talk about three aspects of sexuality: psychological, social and behavioural. They place sexual self-esteem amongst the psychosexual factors of sexual life. When analysing this characteristic, one should remember that almost a decade ago, research confirmed a positive correlation between self-esteem in the sexual aspect and the global self-esteem (Taleporos \& McCabe, 2005).
Psychological needs are viewed by researchers of the phenomenon as dynamic forces that are personality features and their experience determines the functioning of an individual. This applies especially to the lower-order needs (Obuchowski, 1984). Murray, who is one of the best known experts in the field of human needs, defines a need as a "potentiality or readiness to respond in a certain way under certain given circumstances" (Murray, 1938, p. 35).

Sexual needs are usually considered as a component of psychological needs. This approach was mentioned many years ago by Murray (1938), Maslow (1970) and Obuchowski (1984). Each one of them would discuss it in a specific, slightly distinct way. These scientific descriptions give a basis to define sexual needs as: "biologically determined properties of the organism, exhibited as the pursuance of achieving sexual satisfaction through a discharge of the periodically appearing psychophysical tension, as a result of engaging in adequate sexual activities, which ensure the possibility of experiencing sensual pleasures". These needs, while being biologically determined, involve psychological and social components such as attitudes towards one's body and entering gender roles, perception of physical attractiveness or lack thereof, fascination by the opposite sex, a system of values regarding sex life, etc. (Lew-Starowicz, 1999). In the course of the development of an individual, sexual needs undergo a process of materialisation (moving from ineffective behaviours to those providing desired results in terms of sexual satisfaction), mentalisation (the awareness of the existence of one's own sexual needs, and finding ways for their fulfilment that are compatible with the existing preferences) and socialization (subjecting oneself to the existing norms, and the hierarchy of values with regards to ways of fulfilment of sexual needs) (Gapik, 2009).

Every individual with a certain degree of disability, irrespective of the type of disability, is at risk of experiencing physical, psychological and social problems (Lipczyński, 2010). One of the most common reasons for disability is cerebral palsy (CP) (Stevenson, Pharoah, \& Stevenson, 1997; Donkervoort, Roebroeck, Wiegierink, Heijden-Maesssen, \& Stam, 2007). It is most frequently defined as "a group of permanent disorders in the development of posture and movement which cause limitations in activities and is attributed to non-progressive disturbances that occur in the developing brain of a fetus or baby" (Rosenbaum et al., 2007, p. 9).

The lack of full motor ability, and frequently occurring overprotectiveness and overzealous level of care experienced from parents, often hinder the possibility of independent functioning of children and youth with $\mathrm{CP}$, at the same time significantly limiting their social contacts (Blum, Resnick, Nelson, \& Germaine, 1991; Kurpiel, 2011). Additionally, it is possible to observe the deprivation of some of the psychological needs of this social group in various 
contexts. The need for safety might be disrupted by the frequent travels to rehabilitation clinics. The need to belong, need for recognition and need for approval when neglected create feelings of rejection by others. Relatively commonly, this leads to increased frustration, emotional problems, and a negative attitude towards one's social environment (Król, 2010).

The uniqueness of the issues of sexuality of the disabled is also highlighted by the analyses and results of scientific research in this area. This is not only because of the meaning of the results, but also because of the small number of studies, many methodological difficulties and shortcomings, and very selective treatment of human sexuality, especially in consideration of people with certain types of disability (Czusz, Otrębski, in press; Kijak, 2014).

Among the conclusions presented by the researchers of this phenomenon is the most important one: the confirmation of the existence of a sexual sphere in the life of the disabled, debunking the myth of asexuality of the disabled. At the same time, data indicate the existence of a wide range of problems with experiencing and fruition of one's sexuality for the disabled. The lack of full participation in social life delays the process of mentalisation and materialisation of sexual needs, at the same time significantly limiting the opportunities to gather knowledge about sexuality, making it more difficult to find a partner and to attain sexual activity (Rintala, Howland, \& Nosek, 1997; Gordon, Tschopp, \& Feldman, 2004; Radomski, 2005).

Detailed analyses of some of the research results suggest that:

- Disabled adolescents in Sweden give more weight to their sexuality and sexual initiation than their able-bodied peers (Brunnberg, Bostrom, \& Berglund, 2009);

- Sexual needs of disabled women are at a level that is comparable to the levels of sexual needs in the population of able-bodied women (Moin et al., 2009);

- The level of sexual needs experienced by the disabled is lower than for fully-able individuals (Kirenko \& Lew-Starowicz, 1998, 2001).

Until now, there has been a limited number of studies focused on the sexual self-esteem of disabled people. The investigations of the correlations between sexual self-esteem, global self-esteem and body image revealed a stronger correlation between the first two for men, and a stronger correlation between sexual self-esteem and body image for women (Taleporos et al., 2002). Moin et al. (2009), who examined disabled women, found that their sexual self-esteem is significantly lower than that of able-bodied women. What is more, disabled women experience problems in finding a partner for dating, which is strongly connected to their low self-esteem (including sexual self-esteem) and the perception of having no physical attractiveness in the eyes of men (Rintala et al., 1997; Wiegierink, Roebroeck, Donkevoort,
Stam, \& Cohen-Kettenis, 2006). Previously experienced meetings left them feeling displeased and stimulated a realisation of their own social and personal barriers with regards to dating (Nosek, Howland, Rintala, Young, \& Chanpong, 2001). In Poland, Kirenko (2004), investigating people with spinal cord injury and tetra- and paraplegics, also found that they exhibit a lower sexual self-esteem with comparison to able-bodied individuals.

In the available literature about sexuality of our group of interest, which is people with $\mathrm{CP}$, there is a strong tendency among the authors to concentrate mainly on the aspect of engaging in sexual activity. They show that these individuals start dating and go through sexual initiation later than their ablebodied peers (Wiegierink, Roebroeck, Donkevoort, Cohen-Kettins, \& Stam, 2008; Wiegierink, Stam, Ketelaar, Cohen-Kettenis, \& Roebroeck, 2012). One also finds that, in most cases, CP does not prevent them from engaging in autoerotic behaviours, which are more common among men than women in this group (Wiegierink, Roebroeck, van der Slot, Stam, \& Cohen-Kettenis, 2010). Their knowledge about sexuality is lower than that of their able-bodied peers (Wiegierink et al., 2006; Wiegierink, Roebroeck, Bender, Stam, \& Cohen-Kettenis, 2011). Interestingly, there are some differences in the development of secondary sex characteristics. Adolescents with $\mathrm{CP}$ start such development earlier, but it takes longer to complete than for their able-bodied peers (Worley et al., 2002).

The above results indicate a clear need for further exploration of the phenomenon and broadening the current knowledge about the sexuality of those affected by CP. Research concerned with young adults with $\mathrm{CP}$ is particularly valuable and needed from the point of view of social rehabilitation. Taking on this challenge, we prepared and completed a research project which allowed us to gather preliminary data regarding the self-esteem levels and sexual needs of young adults with $\mathrm{CP}$. The details of methodology of the reported study, its results and conclusion are presented below.

\section{PARTICIPANTS AND PROCEDURE}

The study was carried out in Poland with a group of 61 people with roughly equal proportions of men and women. Subject selection was non-random; every subject was diagnosed with $\mathrm{CP}$ and was aged between 15 and 25. All of the subjects had normal levels of intelligence.

The study was partially conducted via e-mail and partially using a paper and pencil method. Subjects received the research tools combined into a 'battery of tests', then answered the questions by marking one of the options to choose from, either on their own, or with the assistance of a researcher. Every
Sexual behavior of youth with cerebral palsy 
examination was conducted as a single, one-on-one interaction. All of the respondents were informed about the anonymity and consent and about the fact that they could withdraw from the study at any stage of filling in the questionnaire (if they decided that certain questions dealt with intimate matters that they would not like to share).

\section{METHOD}

Klaudia Czapla, Wojciech Otrębski

Two research tools were used in the study: Skala do badania samooceny seksualnej (subsequently referred to in English as the Sexual Self-esteem Scale) and Skala do badania potrzeb seksualnych (subsequently referred to in English as the Sexual Needs Scale). Due to the lack of availability of fully adequate tools, there was a need to adapt the existing ones.

The Sexual Self-esteem Scale is the Sexuality Scale (SS) by Snell and Papini translated by the authors of the current article from English to Polish. The scale is used to measure three aspects of human sexuality: sexual self-esteem, sexual depression and sexual preoccupation. It consists of 10 items with a 5-level response scale: "I disagree", "I slightly disagree", "I neither agree nor disagree", "I slightly agree", or "I agree" (Snell \& Papini, 1989). Due to the nature of the investigated group the modified Sexual Self-esteem Scale included an option of visualising oneself in a given activity, which gave the possibility of choosing an answer for subjects who were not sexually active at the time and/or had never been sexually active, but would like to be sexually active in the future. As a result we obtained information about the respondents' assessment of themselves in the role of a sexual partner. The reliability analysis conducted with 61 subjects revealed that the Cronbach $\alpha$ coefficient was 91.

The Sexual Needs Scale was constructed by the authors of the publication based on two other scales used to measure sexual needs. The first is a scale of psychological needs developed by M. Skarżyńska-Gawrońska under the supervision of Stanisław Siek (translation). It is a Polish adaptation of Murray's scale of psychological needs (1954; qtd. in: Siek, 1993,

Table 1

Group characteristics

\begin{tabular}{lcc}
\hline \multirow{2}{*}{ Age } & $M$ & $S D$ \\
& 21.03 & 2.70 \\
Sex & Male (\%) & Female (\%) \\
& 49.20 & 50.80 \\
Education & University & Secondary educa- \\
& students (\%) & tion students (\%) \\
& 18.00 & 82.00 \\
\hline
\end{tabular}

p. 87). It consists of 109 items, where the answers are given on a 4-level scale. It includes 19 overt psychological needs. One of them is the sexual need, represented by 10 items. The second method used was the sexual needs and reactions MELL-KRAT scale for women (SFK-K), and for men (SFK-M). The version for women consists of 20 items, and for men it consists of 13. Respondents give answers on a five-level scale of 0 to 4 , and the score is calculated as a sum of points for individual items in the test (Robacha, 2010). The Sexual Needs Scale, which is a modification of the two aforementioned scales, was divided into two parts. PART 1 is based on the Siek questionnaire and consists of 9 instead of the original 10 items. PART 2 consists of 2 items taken from the MELL-KRAT scale that reveal an additional aspect of sexual needs - the willingness for sexual contacts and the preferred frequency of such. The newly constructed scale eventually sums up to 11 items divided into two parts, where the first part contains 9 items and the second part contains 2 . The answers to both parts are chosen from 5 categorical qualitatively different statements. As a result we obtain information about the assessment of sexual needs and their intensity. The reliability analysis conducted with 61 subjects revealed that the Cronbach $\alpha$ coefficient was .84 (Table 1).

\section{RESULTS}

The results in terms of sexual self-esteem and sexual needs allowed us to distinguish between two different subgroups of subjects. The criterion for including a subject in one of the subgroups was the similarity in answers for 16 out of 21 questions forming the two scales, which resulted in $78.18 \%$ convergence of the answers of people included in the given pool. This allowed two clearly different subgroups to be distinguished ( $\mathrm{H}$ - with high scores; $\mathrm{L}$ - with low scores) (Table 2).

The analysis of significance levels of the differences in terms of sexual esteem and sexual needs between subgroups $\mathrm{H}$ and $\mathrm{L}$ confirmed the clear distinction between each of the subgroups' clinical

Table 2

Distribution of individuals in subgroups $H$ and $L$ : quantity $(f)$ and percentage $(P)$

\begin{tabular}{lcc}
\hline \multicolumn{1}{c}{ Subgroups } & $f$ & $\mathrm{P}$ \\
\hline $\begin{array}{l}\text { High sexual self-esteem } \\
\text { and sexual needs }(\mathrm{H})\end{array}$ & 22 & 36.00 \\
$\begin{array}{l}\text { Low sexual self-esteem } \\
\text { and sexual needs }(\mathrm{L})\end{array}$ & 39 & 64.00 \\
\hline
\end{tabular}


Table 3

Distribution of individuals choosing given categories of answers with regards to their self-esteem and sexual needs: quantity $(f)$, percentage $(P)$ and the significance of the differences in their distribution

\begin{tabular}{|c|c|c|c|c|c|c|c|}
\hline & \multirow[t]{2}{*}{$\begin{array}{l}\text { Category of } \\
\text { answer }\end{array}$} & \multicolumn{2}{|c|}{$\begin{array}{l}\text { High sexual } \\
\text { self-esteem } \\
\text { and sexual } \\
\text { needs }\end{array}$} & \multicolumn{2}{|c|}{$\begin{array}{l}\text { Low sexual } \\
\text { self-esteem } \\
\text { and sexual } \\
\text { needs (L) }\end{array}$} & \multicolumn{2}{|c|}{$\chi^{2}$ statistics } \\
\hline & & $f$ & $\mathrm{P}$ & $f$ & $\mathrm{P}$ & $\chi^{2}$ & $p$ \\
\hline \multirow{3}{*}{$\begin{array}{l}\text { I would rate myself low as a sexual } \\
\text { partner }\end{array}$} & No & 19 & 86.40 & 1 & 2.60 & \multirow{3}{*}{48.87} & \multirow{3}{*}{$<.001$} \\
\hline & I don't know & 2 & 9.10 & 4 & 10.20 & & \\
\hline & Yes & 1 & 4.50 & 34 & 87.20 & & \\
\hline \multirow{3}{*}{ I am a good sexual partner } & No & 1 & 4.50 & 37 & 94.90 & \multirow{3}{*}{53.78} & \multirow{3}{*}{$<.001$} \\
\hline & I don't know & 0 & 0.00 & 2 & 5.10 & & \\
\hline & Yes & 21 & 95.50 & 0 & 0.00 & & \\
\hline \multirow{3}{*}{$\begin{array}{l}\text { I would rate my sexual skill quite } \\
\text { highly }\end{array}$} & No & 0 & 0.00 & 33 & 84.60 & \multirow{3}{*}{45.67} & \multirow{3}{*}{$<.001$} \\
\hline & I don't know & 6 & 27.30 & 5 & 12.90 & & \\
\hline & Yes & 16 & 72.70 & 1 & 2.50 & & \\
\hline \multirow{3}{*}{$\begin{array}{l}\text { I am better at sex than most other } \\
\text { people }\end{array}$} & No & 6 & 27.30 & 35 & 89.80 & \multirow{3}{*}{31.54} & \multirow{3}{*}{$<.001$} \\
\hline & I don't know & 3 & 13.60 & 4 & 10.20 & & \\
\hline & Yes & 13 & 59.10 & 0 & 0.00 & & \\
\hline \multirow{3}{*}{$\begin{array}{l}\text { I sometimes have doubts about my } \\
\text { sexual competence }\end{array}$} & No & 20 & 91.00 & 7 & 18.00 & \multirow{3}{*}{34.98} & \multirow{3}{*}{$<.001$} \\
\hline & I don't know & 1 & 4.50 & 1 & 2.60 & & \\
\hline & Yes & 1 & 4.50 & 31 & 79.40 & & \\
\hline \multirow{3}{*}{$\begin{array}{l}\text { I think of myself as a very good sexu- } \\
\text { al partner }\end{array}$} & No & 4 & 18.20 & 33 & 84.60 & \multirow{3}{*}{38.99} & \multirow{3}{*}{$<.001$} \\
\hline & I don't know & 1 & 4.50 & 6 & 15.40 & & \\
\hline & Yes & 17 & 77.30 & 0 & 0.00 & & \\
\hline \multirow{3}{*}{$\begin{array}{l}\text { I am not very confident in sexual } \\
\text { encounters }\end{array}$} & No & 21 & 95.50 & 4 & 10.30 & & \\
\hline & I don't know & 0 & 0.00 & 8 & 20.50 & 35.21 & $<.001$ \\
\hline & Yes & 1 & 4.50 & 27 & 69.20 & & \\
\hline I am confident about myself as a sex- & No & 1 & 4.50 & 34 & 87.20 & & \\
\hline ual partner & I don't know & 1 & 4.50 & 4 & 10.20 & 36.70 & $<.001$ \\
\hline & Yes & 20 & 91.00 & 1 & 2.60 & & \\
\hline I am not very confident about myself & No & 19 & 86.40 & 2 & 5.10 & & \\
\hline as a sexual partner & I don't know & 0 & 0.00 & 3 & 7.70 & 38.61 & $<.001$ \\
\hline & Yes & 3 & 13.60 & 34 & 87.20 & & \\
\hline I sometimes doubt my sexual compe- & No & 19 & 86.50 & 2 & 5.10 & & \\
\hline tence & I don't know & 2 & 9.00 & 4 & 10.30 & 41.85 & $<.001$ \\
\hline & Yes & 1 & 4.50 & 33 & 84.60 & & \\
\hline & No & 10 & 45.50 & 29 & 74.40 & & \\
\hline I fall in love easily & I don't know & 4 & 18.20 & 2 & 5.10 & 3.06 & .080 \\
\hline & Yes & 8 & 36.30 & 8 & 20.50 & & \\
\hline & No & 2 & 9.00 & 25 & 64.10 & & \\
\hline I think a lot about sexual matters & I don't know & 0 & 0.00 & 1 & 2.60 & 18.10 & $<.001$ \\
\hline & Yes & 20 & 91.00 & 13 & 33.30 & & \\
\hline & No & 2 & 9.00 & 30 & 76.80 & & \\
\hline I have had sexual experiences & I don't know & 6 & 27.30 & 4 & 10.30 & 25.18 & $<.001$ \\
\hline & Yes & 14 & 63.70 & 5 & 12.90 & & \\
\hline & No & 1 & 4.50 & 22 & 56.40 & & \\
\hline sexually attractive than others & I don't know & 3 & 13.60 & 7 & 17.90 & 19.41 & $<.001$ \\
\hline & Yes & 18 & 81.90 & 10 & 25.70 & & \\
\hline
\end{tabular}


Klaudia Czapla, Wojciech Otrębski

\begin{tabular}{|c|c|c|c|c|c|c|c|}
\hline & \multirow[t]{2}{*}{$\begin{array}{l}\text { Category of } \\
\text { answer }\end{array}$} & \multicolumn{2}{|c|}{$\begin{array}{l}\text { High sexual } \\
\text { self-esteem } \\
\text { and sexual } \\
\text { needs }\end{array}$} & \multicolumn{2}{|c|}{$\begin{array}{l}\text { Low sexual } \\
\text { self-esteem } \\
\text { and sexual } \\
\text { needs }(\mathrm{L})\end{array}$} & \multicolumn{2}{|c|}{$\chi^{2}$ statistics } \\
\hline & & $f$ & $\mathrm{P}$ & $f$ & $\mathrm{P}$ & $\chi^{2}$ & $p$ \\
\hline \multirow{3}{*}{$\begin{array}{l}\text { I am attracted to any pretty/hand- } \\
\text { some woman/man }\end{array}$} & No & 4 & 18.20 & 26 & 66.70 & \multirow{3}{*}{20.48} & \multirow{3}{*}{$<.001$} \\
\hline & I don't know & 2 & 9.00 & 8 & 20.50 & & \\
\hline & Yes & 16 & 72.80 & 5 & 12.80 & & \\
\hline \multirow{3}{*}{$\begin{array}{l}\text { I have problems with control over my } \\
\text { sexual impulses }\end{array}$} & No & 13 & 59.10 & 36 & 92.30 & \multirow{3}{*}{11.83} & \multirow{3}{*}{$<.001$} \\
\hline & I don't know & 0 & 0.00 & 1 & 2.60 & & \\
\hline & Yes & 9 & 40.90 & 2 & 5.10 & & \\
\hline \multirow{3}{*}{$\begin{array}{l}\text { I spend a lot of time having elaborate } \\
\text { sexual fantasies }\end{array}$} & No & 5 & 22.70 & 38 & 97.40 & \multirow{3}{*}{36.44} & \multirow{3}{*}{$<.001$} \\
\hline & I don't know & 1 & 4.50 & 0 & 0.00 & & \\
\hline & Yes & 16 & 72.80 & 1 & 2.60 & & \\
\hline \multirow{3}{*}{$\begin{array}{l}\text { I look at every attractive member } \\
\text { of the opposite sex with curiosity, } \\
\text { watch them head to toe, investigat- } \\
\text { ing and assessing the possibility of } \\
\text { making contact }\end{array}$} & No & 8 & 36.40 & 35 & 89.70 & \multirow{3}{*}{13.40} & \multirow{3}{*}{$<.001$} \\
\hline & I don't know & 4 & 18.20 & 1 & 2.60 & & \\
\hline & Yes & 10 & 45.40 & 3 & 7.70 & & \\
\hline \multirow{3}{*}{$\begin{array}{l}\text { I feel that my sexual instinct (drive) } \\
\text { is as strong as my ambition }\end{array}$} & No & 5 & 22.70 & 35 & 89.70 & \multirow{3}{*}{27.16} & \multirow{3}{*}{$<.001$} \\
\hline & I don't know & 5 & 22.70 & 3 & 7.70 & & \\
\hline & Yes & 12 & 54.60 & 1 & 2.60 & & \\
\hline
\end{tabular}

pictures $(p<.001)$ in 20 out of 21 of the analysed aspects. Falling in love was the only matter that did not differentiate the subgroups (Table 3 ).

Thirty-six percent of the total group of subjects fell into subgroup $\mathrm{H}$, which represents people with high sexual self-esteem and sexual needs (Table 2). The results revealed an image of individuals who, in their sexual lives, were or would have been self-confident, confident in their abilities and knew that they were/would have been good sexual partners (about $90 \%$ of people from group $\mathrm{H}$ ). Moreover, they preferred frequent sexual contacts (every day, or at least a few times a week), and they reported thinking a lot about sexual matters. Sexual life and its fulfilment in their perception was an important aspect of functioning. Most of them assessed themselves as good sexual partners (almost everyone in group $\mathrm{H}$ ), assessed their sexual skills/abilities as high (70\% of the respondents from group $\mathrm{H}$ ) and they reported not worrying about them (almost 90\%). Individuals from subgroup $\mathrm{H}$ were more likely to claim that they would be better at sex than most other people than those in group $\mathrm{L}$ (almost $60 \%$ of the respondents in group H). Almost all of them felt comfortable and at ease in their sexual relationships (Table 3). Individuals from subgroup $\mathrm{H}$ also declared that they spend a lot of time having elaborate sexual fantasies (more than 70\%) and their attention and interests are directed at opposite-sex individuals assessed as attractive (2/3 of the respondents). They reported to treat the fulfilment of sexual lives with ambition and they admitted having problems with control of their sexual impulses (almost half of the subjects in this subgroup) (Table 3 ).

A completely different image of sexual self-esteem and sexual needs characterized subgroup L, representing $64 \%$ of the total group of respondents (Table 3). These individuals appeared unconfident in their sexual skills/abilities, and they thought they would feel bad, or actually felt bad, in the role of a sexual partner (about $80 \%$ of the respondents in subgroup L). Moreover, they did not perceive themselves as better than others at sex (almost $90 \%$ of the individuals), and they did not feel self-confident in sexual encounters (slightly over $70 \%$ of the subjects in this subgroup). Sexual matters and sex life rarely occupied their thoughts (almost $60 \%$ of the subjects in this subgroup reported having no thoughts about sexual matters). Sexual matters did not constitute an important aspect of their functioning - they did not spend time on sexual fantasies (almost everyone in the subgroup), they claimed to not treat sexual activity as an ambition (almost $80 \%$ of subjects in the subgroup). These individuals did not report experiencing problems in control over their sexual impulses (over $90 \%$ of the respondents) and they did not report paying much attention to attractive individuals (about $80 \%$ of the subjects in 
subgroup L). If they reported wanting to be sexually active, they claimed they would fulfil these needs with a much lower frequency (a few times a year, or at most once a month) than the people in the high sexual self-esteem and sexual needs subgroup (Table 3 ).

\section{DISCUSSION}

The above results of the current study, regarding the sexual self-esteem and sexual needs of young adults with $\mathrm{CP}$, clearly broaden the image of sexuality of this group previously presented in the literature.

There is a clear polarization of the results. Only $1 / 3$ of the respondents had high sexual self-esteem and sexual needs. The remaining $2 / 3$ reported having a rather low level of sexual self-esteem and low levels of needs with regards to their own sexuality. Looking for an explanation of such a situation, one can refer to the analyses conducted by Szczerba (2004), who pointed out that young people, at a certain moment after specifying their sexual drive, choose one of two alternatives: the decision to be sexually active and to have a sex life, or to restrain from sexual activity and sublimate/suppress their sexual needs. These behaviours (sublimation or suppression of sexual needs) can also be explained through the fact that individuals with $\mathrm{CP}$, having various causes of difficulties in entering social relations, try to postpone this aspect of their lives, or temporarily abstain from it (Wiegierink et al., 2012).

An important factor for young adults with $\mathrm{CP}$ in the decision to implement one's own sexuality is the commonly experienced overprotective attitude of their parents, and the clearly negative signals about the possibility of initiating a sex life and starting a family, that parents send to their children (Blum et al., 1991). It should be noted that quite often, the disabled would have less knowledge about sexuality than their peers, and they would experience fears associated with engaging in sexual activity, which is why they remain restrained or suppress their needs in that sphere (Wiegierink et al., 2006). What is more, the process of materialisation and mentalisation occurs slightly later than in their able-bodied peers (Długołęcka, 2007). It could therefore be the case that the sexual needs are not yet as important and precise for the young disabled as for their able-bodied peers.

In terms of self-esteem, another reason could be added to the above listed reasons for the majority of negative results among the respondents. Negative stereotypes exist about sexual matters and the possibility of starting a family for the disabled. These stereotypes are frequently uttered by the family and friends of the physically disabled, which may result in the lowering of self-esteem of the disabled individuals in that aspect (Blum et al., 1991; Długołęcka,
2007). The negative consequences of this situation for the future married life of individuals affected by $\mathrm{CP}$ are described in a study from South Korea (Cho, Park, Park, \& Na, 2004).

Summing up, it needs to be stressed that CP-affected youth, similarly to their peers, may need support in discovering their sexuality and satisfying their sexual needs ( $2 / 3$ of the respondents). The specificity of the range of support should take into account the aspects highlighted by the literature as associated with the causes of disability and contexts of psychosocial functioning of individual with $\mathrm{CP}$.

ENDNOTES

1 Originally in Polish

\section{REFERENCES}

Blum, R.W., Resnick, M. D., Nelson, R., \& Germaine, A. (1991). Family and peer issues among adolescents with spina bifida and cerebral palsy. Pediatrics, 88 , 280-285.

Brunnberg, E., Bostrom, M. L., \& Berglund, M. (2009). Sexuality of 15/16-years-old girls and boys with and without modest disabilities. Sexuality and Disability, 27, 139-153.

Campbell, J. D., \& Lavaalle L. F. (1993). Who I am? The role of self-concept confusion in understanding behavior of people with low self-esteem. In: R. F. Baumeister (ed.), Self-Esteem (pp. 3-20). New York: Plenum Press.

Cho, S.-R., Park, E. S., Park, Ch. II, \& Na, S.-il. (2004). Characterictics of psychosexual functioning in adults with cerebral palsy. Clinical Rehabilitation, 18, 423-429.

Czusz, A., \& Otrębski, W. (in press). Seksualność osób niepełnosprawnych umysłowo - wyzwanie dla metodologii badań i praktyki psychologicznej [Sexuality of intellectually disabled individuals - a challenge for research methodology and psychological practice]. In: E. Zasępa (ed.), Konteksty psychologii klinicznej [Contexts of clinical psychology]. Warsaw: Wydawnictwo APS.

Długołęcka, A. (2007). Seksualność osób niepełnosprawnych fizycznie - zarys problemów [Sexuality of physically disabled individuals - an outline of problems]. In: A. Ostrowska (ed.), O seksualności osób niepetnosprawnych [About the sexuality of disabled individuals] (pp. 97-105). Warsaw: Wydawnictwo "GARMOND".

Donkervoort, M., Roebroeck, M., Wiegierink, D., Heijden-Maesssen, H., \& Stam, H. (2007). Determinants of functioning of adolescents and young adults with cerebral palsy. Disability and Rehabilitation, 29, 456-463.
Sexual behavior of youth with cerebral palsy 
Klaudia Czapla, Wojciech Otrębski
Gapik, L. (2009). Funkcjonowanie seksualne w normie i patologii [Sexual functioning in normal and pathological cases]. In: Z. Izdebski (ed.), O człowieku i jego rozwoju nie tylko seksualnym: prace dedykowane profesorowi Andrzejowi Jaczewskiemu [About humans and their development, not just sexual: works dedicated to Professor Andrzej Jaczewski] (pp. 227-270). Zielona Góra: Oficyna Wydawnicza Uniwersytetu Zielonogórskiego.

Gordon, P. A., Tschopp, M. K., \& Feldman, D. (2004). Addressing issues of sexuality with adolescents with disabilities. Child and Adolescent Social Work Journal, 21, 513-527.

Kijak, R. (2014). Seksualność człowieka z niepetnosprawnościq intelektualna a rodzina [Sexuality of an intellectually disabled individual and the family]. Warszawa: Wydawnictwo Lekarskie PZWL.

Kirenko, J., \& Lew-Starowicz, Z. (1998). Psychospoteczne determinanty funkcjonowania seksualnego osób z uszkodzeniem rdzenia kręgowego [Psychosocial determinants of sexual functioning of individuals with spinal cord injury]. Lublin: Wydawnictwo UMCS.

Kirenko, J., \& Lew-Starowicz, Z. (2001). Seks po uszkodzeniu rdzenia kręgowego [Sex after spinal cord injury]. Lublin: Wydawnictwo UMCS.

Kirenko, J. (2004). Psychospołeczne korelaty funkcjonowania seksualnego osób niepełnosprawnych ruchowo [Psychosocial correlates of sexual functioning of individuals with motor disabilities]. In: M. Kościelska, \& B. Aouila (eds.), Człowiek niepetnosprawny. Rodzina i praca [The disabled individual. Family and work] (pp. 122-134). Bydgoszcz: Wydawnictwo Akademii Bydgoskiej.

Król, M. (2010). Mózgowe porażenie dziecięce [Cerebral Palsy]. Warsaw: Wydawnictwo Harmonia.

Kurpiel, D. (2011). Psychospołeczne uwarunkowania funkcjonowania osób dorostych z mózgowym porażeniem dziecięcym o różnym zakresie niepetnosprawności [Psychosocial determinants of functioning of adults with cerebral palsy and different levels of disability]. Cracow: Oficyna Wydawnicza Impuls.

Lew-Starowicz, Z. (1999). Stownik encyklopedyczny. Miłość i seks [Encyclopaedic dictionary. Love and sex]. Wrocław: Wydawnictwo Europa.

Lipczyński, A. (2010). Niektóre psychologiczne aspekty problemów seksualnych w zwiqzzku z niepetnosprawnościa [Some psychological aspects of sexual problems associated with disability]. Accessed on: 14.05.2013, source: http://www.psychologia. net.pl/artykul.php?level=133.

Markus, H. (1977). Self-schemata and processing information about self. Journal of Personality and Social Psychology, 35, 63-78.

Maslow, A. H. (1970). Motivation and personality $\left(2^{\text {nd }}\right)$. New York: Harper \& Row.

Moin, V., Duvdevany, I., \& Mazor, D. (2009). Sexual identity, body image and life satisfaction among woman with and without physical disability. Sexuality and Disability, 27, 83-95.

Murray, H. A. (1938). Explorations in personality. New York: Oxford University Press.

Nosek, M. A., Howland, C., Rintala, D. H., Young, M. K., \& Chanpong, G. F. (2001). National study of woman with physical disabilities: final report. Sexuality and Disability, 19, 5-38.

Obuchowski, K. (1984). Psychologiczne problemy seksuologii [Psychological problems of sexology]. In: K. Imieliński (ed.), Seksuologia społeczna [Social sexology] (pp. 219-269). Warsaw: Wydawnictwo Naukowe PWN.

Porębiak, M. I. (2005). Samoocena jawna i utajona: model dwuskładnikowy [Covert and overt self-esteem: a two-component model]. Nowiny Psychologiczne, 2, 93-105.

Radomski, D. (2005). Czynniki utrudniające realizację życia erotycznego osób niepełnosprawnych fizycznie [Factors hindering the sexual life of people with physical disabilities]. Seksuologia Polska, 3, 8-12.

Rintala, D. H., Howland, C. A., \& Nosek, M. A. (1997). Dating issues for women with physical disabilities. Sexuality and Disability, 13, 219-241.

Robacha, A. (2010). Metody badań seksuologicznych [Methods of sexology research]. In: Z. LewStarowicz, \& V. Skrzypulec (eds.), Podstawy seksuologii (wyd. 1) [The basics of sexology, ${ }^{\text {st }}$ ed.] (pp. 355-370). Warsaw: Wydawnictwo Lekarskie PZWL.

Rosenbaum, P., Paneth, N., Levinton A., Goldstein M., Bax, M., Damiano, D. (2007). A report: the definition and classification of cerebral palsy. Developmental Medicine \& Child Neurology. Supplement, 109, 8-14.

Siek, S. (1993). Wybrane metody badania osobowości. Wydanie drugie, poprawione i rozszerzone [Selected methods of studying personality. Second edition, revised and expanded]. Warsaw: Wydawnictwo Akademii Teologii Katolickiej.

Snell, W. E., \& Papini, D. R. (1989). The sexuality scale an instrument to measure sexual-esteem, sexual-depression and sexual-preoccupation. The Journal of Sex Research, 26, 256-263.

Stevenson, C. J., Pharoah, P. O., \& Stevenson, R. (1997). Cerebral palsy - the transition from youth to adulthood. Developmental Medicine \& Child Neurology, 39, 336-342.

Szczerba, K. (2004). Seks od początku do spełnienia [Sex from the beginning to the climax]. Charaktery, 5, 37-39.

Taleporos, G., \& McCabe, M. P. (2005). The relationship between the severity and duration of physical disability and body esteem. Psychology of Health, 20, 637-650.

Taleporos, G., Hons, B. A., Dip, G., \& McCabe, M. (2002). Development and validation of the physical disability sexual and body esteem scale. Sexuality and Disability, 20, 159-175. 
Wiegierink, D., Roebroeck, M., Bender, J., Stam, H., \& Cohen-Kettenis, P. (2011). Sexuality of young adults with cerebral palsy: experienced limitation and needs. Sexuality and Disability, 29, 119-128.

Wiegierink, D., Roebroeck, M. E., Donkevoort, M., Stam, H., \& Cohen-Kettenis, P. T. (2006). Social and sexual relationships of adolescents and young adults with cerebral palsy: a review. Clinical Rehabilitation, 20, 1023-1031.

Wiegierink, D., Roebroeck, M., Donkevoort, M., Cohen-Kettenis, P. T., \& Stam, H. (2008). Social, intimate and sexual relationships of adolescents with cerebral palsy compared with able-bodied age-mates. Journal of Rehabilitation Medicine, 40, 112-118.

Wiegierink, D., Roebroeck, M. E., van der Slot, W. M., Stam, H. J., \& Cohen-Kettenis, P. T. (2010). Importance of peers and dating in the development of romantic relationships and sexual activity of young adults with cerebral palsy. Developmental Medicine \& Child Neurology, 52, 576-582.

Wiegierink, D., Stam, H. J., Ketelaar, M., Cohen-Kettenis, P. T., \& Roebroeck, M. E. (2012). Personal and environmental factors contributing to participation in romantic relationships and sexual activity of young adult with cerebral palsy. Disability and Rehabilitation, 34, 1481-1487.

Worley, G., Houlihan, C. M., Herman-Giddens, M. E., O’Donnel, M. E., Conaway, M., \& Stallings, V. A. (2002). Secondary sexual characteristics in children with cerebral palsy and moderate to severe motor impairment: a cross-sectional survey. Pediatrics, 110, 897-902. 